\title{
Teacher's Preparation of Lesson Plan and Constraints in English as a Foreign Language During the Pandemic Outbreak in the Junior High School
}

\author{
Putu Devi Mas Wulandari $^{1 *}$, Dewa Komang Tantra ${ }^{2}$, Made Hery Santosa ${ }^{3}$ (D) \\ 1,2,3 Ganesha University of Education, Bali, Indonesia
}

\author{
A R T I CLE IN F O \\ Article history: \\ Received February 22, 2021 \\ Revised February 23, 2021 \\ Accepted April 17, 2021 \\ Available online May 25, 2021 \\ Kata Kunci: \\ Rencana Pembelajaran, \\ Persiapan, Kendala \\ Keywords: \\ Lesson Plans, Preparation, \\ Obstacles \\ DOI: \\ http://dx.doi.org/10.23887/jpbi.v9 \\ i1.32518
}

\section{A B S T R A C T}

\begin{abstract}
A B S T R A K
Pengajaran bahasa Inggris melalui online dianggap bermasalah. Ketersediaan support system dan kuota internet menjadi kendala utama. Hal ini berdampak pada kemampuan siswa yang rendah. Tujuan penelitian ini yaitu menganalisi kemampuan dan kendala guru dalam menyusun RPP serta kendala siswa dalam pembelajaran EFL melalui Google Meet pada masa pandemi Covid-19. Sampel penelitian ini adalah seorang guru EFL kelas tujuh dan juga 60 siswa kelas tujuh SMP. Desain yang diterapkan adalah metode campuran. Pengumpulan data menggunakan tiga instrumen yaitu skala penilaian, kendala guru dan kendala siswa dalam EFL melalui Google Meet. Hasil penelitian menunjukkan bahwa dalam menyusun RPP, guru kurang mampu dan memiliki beberapa kendala dalam: pemilihan metode atau teknik pembelajaran, pemilihan instrumen dan teknik evaluasi dan pemilihan media pembelajaran. Selain itu, hasil penelitian menunjukkan bahwa siswa tidak memahami materi dalam RPP 3 dan 4 dan tidak suka menggunakan Google Meet dalam pembelajaran bahasa Inggris berdasarkan RPP 1,3 dan 4. Hal ini terkait dengan keterbatasan siswa dalam kaitannya. Penelitian ini menyiratkan bahwa guru EFL menyediakan rencana pembelajaran online dan fokus pada pemilihan teknik atau metode, proses evaluasi dan media.
\end{abstract}

Teaching English online is considered problematic. The availability of a support system and internet quota is the main obstacle. This has an impact on the low ability of students. The purpose of this study is to analyze the abilities and constraints of teachers in preparing lesson plans and student obstacles in EFL learning through Google Meet during the Covid-19 pandemic. The sample of this research is a seventh-grade EFL teacher and also 60 seventh-grade junior high school students. The design applied is a mixed method. Data collection uses three instruments: a rating scale, teacher constraints, and student constraints in EFL through Google Meet. The study results indicate that in preparing the lesson plans, teachers are less capable and have several obstacles in choosing learning methods or techniques, selecting instruments and evaluation techniques, and selecting learning media. In addition, the results of the study indicate that students do not understand the material in lesson plans 3 and 4 and do not like to use Google Meet in learning English based on lesson plans 1.3 and 4. This is related to the limitations of students about it. This research implies that EFL teachers provide online learning plans and focus on selecting techniques or methods, evaluation processes, and media.

This is an open-access article under the CC BY-SA license. Copyright (C) 2021 by Author. Published by Universitas Pendidikan Ganesha.

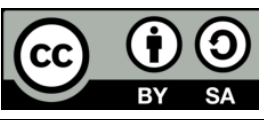

\section{INTRODUCTION}

During the Covid-19 pandemic, there was a change in the implementation of the learning process (Amiti, 2020; Storch et al., 2021). The learning process previously was carried out in schools with a face-to-face system, but during the Covid-19 pandemic, the learning process was carried out from home through the online system by utilizing existing media (Atmojo \& Nugroho, 2020; Mpungose, 2021). During the implementation of online learning, there are many variations of the Learning Management System or applications used in teaching and learning that can be utilized to realize effective learning tools, such as Google Classroom, Google Meet, Video Call Classroom, Schoology (Amin \& Sundari, 2020; Rhim \& Han, 2020). Apart from the Learning Management System that has been mentioned, other applications are often used to support online learning (Ferri et al., 2020; Storch et al., 2021). Taking advantage of the online learning stage especially during a pandemic is new to students and is generally modern for EFL students, especially for Junior High School students and instructors.

Google Meet is an online platform commonly used in the teaching and teaching process during the pandemic (Setyawan et al., 2020; Yunitasari \& Hanifah, 2020). In the implementation of teaching activities, a lecture is a method widely used by educators in learning activities to build knowledge and student learning 
outcomes (Setyawan, Aznam, and Citrawati, 2020). Suitable learning activities require direct communication between educators and students (Pratama et al., 2020; Rusdin, 2018). The material conveyed in building knowledge and learning outcomes can be well-formed, and students' character can be directed through educator guidance. Those components cannot be separated between schools as learning spaces, educators as educators, and students as learners in building knowledge and learning outcomes (Budiarto et al., 2020; Leatherman \& Cleveland, 2020).

Online learning can be categorized effectively because of its online implementation (Bahasoan et al., 2020; Satyawan et al., 2021). However, it was said to be inefficacy because the costs are more than the costs for online learning. Changes in the use of media, methods, strategies, and implementation of learning during an onlinebased pandemic require increased teacher competence and material development as well as other developments such as evaluation instruments (Sriyanti et al., 2021; Sutarto et al., 2020). Teachers are required to develop competencies in preparing learning following the criteria and needs of students as well as the development of objects to be evaluated (Ramkissoon et al., 2020; Raynesa Noor Emiliasari, 2019).

Before the learning activity is implemented online because of the Covid-19 pandemic, lesson plans were organized by Musyawarah Guru Mata Pelajaran (MGMP) Bahasa Inggris or English as a Foreign Language Teachers' Coordinating Group (Herviani \& Budiastuti, 2018). English as a Foreign Language teachers used lesson plans in face-to-face learning or conventional learning in Junior High School. After the outbreak of the Covid-19 pandemic, the Ministry of National Education and Culture alternated English as a Foreign Language learning processes to use an online learning platform. In the implementation of curriculum, the teacher's preparation is the important thing to do before implementing the learning activity (Sari, 2018; Yusoff \& Seman, 2018). Every subject teacher in an education unit is required to prepare lesson plans. A lesson plan is a very important initial stage in guiding teachers to carry out their duties as an educator (Laia, 2019). Meanwhile, the pandemic situation brings a new challenge to the teacher in preparing the lesson plan to achieve the goals in teaching and learning.

Teaching English online is considered problematic (Albashtawi \& Al Bataineh, 2020; Astuti \& Solikhah, 2021). The availability of a support system and internet quotas are the main constraints. The teaching methods used in online teaching are Google meet and Google classroom because students only have androids to access online teaching (Mansyur, 2020; Pratama et al., 2020; Windhiyana, 2020). Government should enlarge the support system and service for students to access the internet quota (Abuhassna et al., 2020). Experience showed that many teachers find some difficulties when planning their lessons, especially those under the component/format on the 2013 curriculum.

The present research looked thoroughly into the teacher's ability to measure the teacher ability in preparing a lesson plan and also teacher's constraints that identified in preparing the lesson plan, as well as students' constraints that identified in learning EFL through online learning platforms especially Google Meet in the Junior High School especially in SMP Negeri 2 Singaraja during Covid-19 pandemic. To become a professional teacher, teachers must carry out a lesson plan to convey subject matter to students systematically and precisely, so that the expected learning objectives can be achieved (Wu \& Chang, 2015; Yafaei \& Attamimi, 2019). A lesson plan as a guide for implementing learning should be prepared by the teacher before learning activities (Indah, 2020; Raynesa Noor Emiliasari, 2019).

Through this condition, the preparation of the implementation of learning is part of the teacher's administrative duties, which directly impacts the interests of learning (Mayarnimar \& Taufina, 2017). Thus, the better the learning planning that is developed, it is believed that the better the learning implementation process will be. It relates with the use of Google Meet as a new thing for Junior High School students especially for SMP Negeri 2 Singaraja teacher and students in learning activity because, before the pandemic, the teacher plan the teaching activity, and also students followed the learning activity conventionally. The purpose of this study is to analyze the preparation of lesson plans and the obstacles of English teachers as a foreign language during the pandemic in junior high school.

\section{METHOD}

The present research was designed using a mixed-method especially embedded mixed method. The mixed method involves incorporating or integrating research and qualitative and quantitative data in research studies (Creswell, 2014). Embedded design is a mixed-method design in which one data set provides a supporting secondary role in studies that are primarily based on other data types. (Creswell, 2014). The objective was to measure and identify EFL teacher's ability in preparing, and constraints found as well as the students' constraints in learning EFL through Google Meet in SMP Negeri 2 Singaraja. The teacher's ability in preparing lesson plans for EFL through Google Meet was measured and described quantitatively by using a rating scale of "Instrumen Penilaian Rencana Persiapan Pembelajaran Undiksha 2020”. Whilst, the teachers' and students' constraints were embedded quantitatively and qualitatively described and analyzed. The instruments were validated before being used by using the Gregory formula. The teachers' ability in preparing lesson plans for EFL through Google Meet 
were rated in terms of $1=$ very poor; $2=$ poor; $3=$ good; 4 = very well (Hinkle et al., 1979). The raw scores were then transformed into T-score $(\mathrm{n} / 32 \times 100)$. There were an EFL teacher and 60 seventh-grade students recruited for the research subjects. The number of students consists of 20 male students and 40 female students for research subjects.

\section{RESULT AND DISCUSSION}

\section{Result}

This research discovered three main findings: 1) teacher's ability in preparing lesson plans with a mean score of 67.50 and categorized into moderate category 2) there are teacher's constraints in preparing a lesson plan, namely: in selecting learning method and technique, selecting evaluation instruments and technique, and selecting learning media, and 3) there are students constraints in EFL learning through Google Meet, namely in joining the online class, connection in following online learning through Google Meet, understanding and prefer EFL learning through Google Meet. The finding was exposed as follow:

Preparing lesson plans for EFL through Google Meet was measured by eight aspects, namely 1) relation of learning indicators with basic competency, 2) relation of learning materials, learning indicators with basic competency, 3) relation learning methods or techniques with learning materials, 4) learning indicators with basic competency, 5) relation of learning procedures or steps in EFL, 6) relation of evaluation and learning indicators, 7) relation of evaluation instruments and techniques with learning indicators, 8) relation of Information Technology to EFL. The lesson plans prepared by one teacher who teaches seventh grade were evaluated by two independent evaluators to ensure validity, reliability, and readability of measurement. The teacher's ability mean score from two evaluators in preparing lesson plans for EFL through Google Meet $=67.50$ When the teacher's ability mean score ordered, the teacher's ability mean score from the first evaluator $=68.40$ is the highest, followed by teacher's ability mean score from the second evaluator $=66.60$. However, when the teacher's ability mean score was categorized, it is all in the moderate category (mean \pm 1 standard deviation or $67.50 \pm 1.27$ ). The variability of scores among EFL teachers is not very large (variance statistic 1.62). The range statistic $=1.80$ between the minimum and maximum scores.

In conclusion, based on the evaluation process were done by two evaluators, the EFL teacher was less able in aspect 3) selecting of learning methods or techniques for students' characteristics, and basic competency as well as learning indicators, aspect 6) evaluating instrument and technique especially in relating to learning indicators, and evaluating learning process and outcome, aspect 7) selecting Google Meet based on the efficient learning platform and effective learning model.

In preparing lesson plans for EFL through Google Meet, the EFL teacher found constraints. The teacher was asked to rate the ability in preparing lesson plans as objectively as possible as they experienced. After selfrating, they described sources or descriptions of constraints in each aspect of lesson plans. The result shows that teachers had constraints in 3 aspects. In aspects 1,2,4,5 and 8, the teacher gave a score of 3 in each lesson plan. Thus, in aspects 3,6, and 7 the teacher gave a score of 2 in each lesson plan. In basic competence 1, 2, and 5 showed that the teacher gave a score of 3 for her lesson plans. The results are categorized into a teacher is able and did not has serious constraints in preparing lesson plans. The analysis of teacher constraints for basic competencies 3 and 4 will be explained in the following paragraph below.

In basic competence 3 showed that the teacher rated the teacher's lesson plan and had a problem in aspects 3,6 , and 7 . In aspect 3, the teacher rated her lesson plan 2 and the converted score is 6 . The teacher had constraints in selecting learning methods or techniques for students' characteristics, and basic competency as well as learning indicators. In aspect 6, the teacher rated her lesson plan 2 and the converted score is 6 . The teacher had constraints in evaluating instruments and techniques especially in relating to learning indicators and evaluating learning process and outcome. In aspect 7, the teacher rated her lesson plan 2 and the converted score is 6 . The teacher had constraints selecting online learning platforms based on the efficient learning platform and effective learning model.

In basic competence 4 showed that the teacher-rated the teacher's lesson plan and had a problem in aspects 3, 6, and 7. In aspect 3, the teacher rated her lesson plan 2 and the converted score is 6 . The teacher had constraints in selecting learning methods or techniques for students' characteristics, and basic competency as well as learning indicators. In aspect 6, the teacher rated her own lesson plan 2 and the converted score is 6 . The teacher had constraints in evaluating instruments and techniques especially in relating to learning indicators and evaluating learning process and outcome. In aspect 7, the teacher rated her own lesson plan 2 and the converted score is 6 . The teacher had constraints selecting online learning platforms based on the efficient learning platform and effective learning model. 
In conclusion, the teacher had constraints especially on basic competencies 3 and 4 in preparing lesson plans through Google Meet during the pandemic. In basic competence 3 and 4 showed that the teacher rated the teacher's lesson plan and had a problem in aspects 3, 6, and 7. In aspect 3, the teacher had constraints in selecting learning methods or techniques for students' characteristics, and basic competency as well as learning indicators. In aspect 6 had constraints in evaluating instrument and technique especially in relating to learning indicators, and evaluating learning process and outcome. In aspect 7 had constraints selecting online learning platforms based on the efficient learning platform and effective learning model.

Students in SMP Negeri 2 Singaraja also found constraints in learning EFL through Google Meet. Their constraints were probed in twenty items: 1) possessing a desktop/laptop/mobile phone, 2) logging to Google Meet without difficulty or others' assistance, 3) using the account to $\log$ in, 4) selecting an account to $\log$ in, 5) $\log$ in without difficulty, 6) joining the online class, 7) switching between accounts, 8) access Google Meet 9) connecting without troubles, 10) posting comments through Google Meet, 11) canceling comments after posting through Google Meet, 12) finding problems with e-mail, either in sending or receiving e-mail, 13) turning in assignments, 14) getting enclosures or handouts from teachers, 15) using wrong language, 16) understanding EFL through Google Meet, 17) liking EFL through Google Meet, 18) being motivated in EFL through Google Meet, 19) perceiving flexibly and positively EFL through Google Meet, and 20) perceiving EFL positively with learning materials, examples or illustrations. In general, the items asked them to disclose some facilitative and technical constraints in learning EFL through online learning platforms especially Google Meet.

The result showed that students found constraints in 1) students' facility by owning laptop/PC/HP $(13.4 \%), 2)$ login to the Google Meet $(21,7 \%, 16.6 \%, 8.3 \%, 8.3 \%$ and $3.3 \%), 3)$ did not have account $(0 \%)$, students already had their account $(100 \%) ; 4)$ login without difficulty or other's assistance $(8.3 \%, 8.3 \%, 3.3 \%$, $3.3 \%, 3.3 \%)$; 5) cannot join the online class 33.3\%, 38.3\%, 48.3\%, 36.7\%, 41.6; 6) switching between accounts $(16.6 \%, 16.6 \%, 13.6 \%, 11.6 \%, 6.6 \%) ; 7)$ logout without difficulty or other's assistance $(20 \%, 16.6 \%, 16.6 \%$, $8.3 \%, 8.3 \%) ; 8)$ access the Google Meet $(31.7 \%, 25 \%, 36 \%, 35 \%, 33.3 \%)$; 9) students' connection in following online learning through Google Meet $(48.3 \%, 41.6 \%, 55 \%, 41.5 \%$ 45\%); 10) posting comments through Google Meet (3.3\%, 3.3\% and 0\%); 11) cancel comments after posting Google Meet (18.4\%, 18.4\%, 13.3\%, 13.3\%, 8.3\%); 12) sending or receiving e-mail $(16.6 \%, 10 \%, 6.6 \%, 6.6 \%, 8.3 \%) ; 13)$ turning assignments $(15 \%, 11.6 \%, 15 \%$, $8.3 \%, 3.3 \%) ; 14)$ getting enclosures or handouts from your teachers $(8.3 \%, 5 \%, 10 \%, 11.6 \%$, and $0 \%)$; 15$)$ use wrong language in Google Meet $(0 \%)$, students understand the language that used in Google Meet $(100 \%)$.

In five aspects, found that students had constraints in EFL learning through Google Meet. The result will be analyzed on each lesson plan. In lesson plan 1, the topic is about Greetings, students had constraints in 1) understanding EFL through Google Meet $(48.3 \%)$, 2) disliking EFL through Google Meet $(50 \%)$, 3) being demotivated in learning EFL Google Meet $(36.7 \%)$, 4) being flexible positively perceived in learning EFL through Google Meet (28.3\%), and 5) perceiving positively to provide them with rich with learning materials, plenty of examples, or varied illustrations $(33.3 \%)$.

In lesson plan 2, the topic is about Introducing Myself, students had constraints in 1) understanding EFL through Google Meet (46.7\%), 2) disliking EFL through Google Meet (48.3\%), 3) being demotivated in learning EFL through Google Meet $(36.7 \%)$, 4) being flexible positively perceived in learning EFL through Google Meet $(28.3 \%)$, and 5) perceiving positively to provide them with rich with learning materials, plenty of examples, or varied illustrations $(38.3 \%)$.

In lesson plan 3, the topic is about Date and Time, students had constraints in 1) understanding EFL through Google Meet (51.6\%), 2) disliking EFL through Google Meet (51.6\%), 3) being demotivated in learning EFL through Google Meet $(43.3 \%)$, 4) constraints in being flexible positively perceived in learning EFL through Google Meet $(33.3 \%$ ), and 5) perceiving positively to provide them with rich with learning materials, plenty of examples, or varied illustrations $(38.3 \%)$.

In lesson plan 4, the topic is about Personal Identity, students had constraints in 1) understanding EFL through Google Meet (55\%), 2) disliking EFL through Google Meet (50\%), 3) being demotivated in learning EFL through Google Meet $(40 \%), 4)$ constraints in being flexible positively perceived in learning EFL through Google Meet (33.3\%), and 5) perceiving positively to provide them with rich with learning materials, plenty of examples, or varied illustrations $(40 \%)$.

In lesson plan 5, the topic is about Things around Us, students had constraints in 1) understanding EFL through Google Meet (45\%), 2) disliking EFL through Google Meet (41.7\%), 3) being demotivated in learning EFL through Google Meet $(36.7 \%)$, 4) constraints in being flexible positively perceived in learning EFL through Google Meet (33.3\%), and 5) perceiving positively to provide them with rich with learning materials, plenty of examples, or varied illustrations $(33.3 \%)$.

Since the introduction of learning from home during the pandemic, online learning is a solution for the continuity of teaching and learning activities (Pratama et al., 2020). The use of Google Meet as an online learning platform is not unusual for junior high school students (Setyawan et al., 2020). During the implementation of online EFL learning through Google, Meet students had constraints in following the EFL learning especially in 
understanding and preferring EFL learning through Google Meet. The analysis of students' explanations will be explained below.

Based on the result, students mostly had constraints in understanding online EFL learning through Google Meet, especially in lesson plan 3 and 4 . This is supported by several samples of student reasons, namely: 1) No, because I find it difficult to understand the material of mentioning time in English, 2) No, because the connection is bad. I don't understand the material, 3) online learning is not fun and I understand what is being taught.

Then, students mostly did not like the use of Google Meet in English lessons, especially in lesson plans 1,2,3, and 4. This is supported by several samples of student reasons, namely: because 1) Not happy, because I can't interact directly with friends and teachers, 2) No, because I find it difficult to understand the material provided especially about pronouns, 3) No, because it's better face-to-face and I understand the material.

The results of this research showed that teacher was less able and also had constraints in preparing a lesson plan for online teaching. Besides, students had constraints in connecting and joining the online class. It related to the students' understanding and preferring EFL learning through Google Meet. The results can be used as a reflection of teachers in preparing lesson plans by conducting appropriate techniques, selecting evaluation, and choosing media in teaching English according to the facilities students have and support for students.

\section{Discussion}

The learning method chosen should use active and effective learning for students to achieve indicators and skills-based 21st century (Hirschman \& Wood, 2018; Sari, 2018). This relates to how teachers map student needs to be based on the appropriateness of media use in delivering material (Rizaldi et al., 2020; Zain, 2017). In connection with the findings above, explained that the basic obstacle to internet-based online learning is the limited support system (Astuti \& Solikhah, 2021). At the planning stage, the teacher refers to K-13 and the syllabus as material for consideration of teaching and material development (Farida et al., 2018). The teacher assesses the teaching of English regarding K-13 which is developed based on knowledge competencies and skills competencies (Mustikawati et al., 2017). The teacher views that in preparing the online teaching is divided into four types: 1) teaching objectives, 2) developing teaching materials, 3) using online teaching techniques, and 4) evaluation processes (Binkley et al., 2012; Churchill et al., 2013). Technology helps teachers to make positive attitudes towards the teaching and learning process, but problems such as lack of time management, the effectiveness of evaluations, students' attention to learning, as well as material development should be considered to reduce the mistakes and mistakes of students and teachers (Khatoony \& Nezhadmehr, 2020; Tondeur et al., 2019). All technology-based classrooms have problems but both teachers and students must pay attention and handle them to be more effective. In addition, teachers considered teaching English through the online system difficult to implement because internet quotas and connections were limited and students did not have access to online platforms well (Agung et al., 2020).

The explanation above also relates to this research finding that also showed students' constraints in connection in following online learning (55\%). It is because some regions with poor internet signals might face many problems in conducting online learning. The main issue of this condition was the internet connection. Network interaction can also present considerable challenges to both teachers and students (Koswara, 2018; Lassoued et al., 2020). Conducting online learning indeed comes with many consequences (Agung et al., 2020; Soucy et al., 2016). Other constraints faced by students in participating in online learning activities are the constraints of a slow internet connection, ignorance of e-learning, and well-being, for example, eye strain experienced by students during online learning (Octaberlina \& Muslimin, 2020).

Some students realized that their IT literacy made good progress during online learning (Azzahra, 2020). The e-learning platforms especially Google Meet allowed users to follow online learning by synchronous learning on personal computers or smartphones while mobile e-learning (Setyawan et al., 2020). In five aspects of EFL through online learning, found that the students' had constraints in understanding online EFL learning through Google Meet and disliking online EFL learning through Google Meet. Online learning is a solution that can help the teaching and learning process amid a pandemic (Allo, 2020; Nartiningrum \& Nugroho, 2020). There were not only reported that online learning was good amid the Covid-19 pandemic but also highlighted the availability of internet access, financial problems, and the implementation of online learning challenges in attending online courses were the unsteady networks and the less direct interactions.

The contribution of this research is to find out the abilities and constraints of the teacher in preparing lesson plans, where preparation is an important stage in designing structured learning. Based on this research, researchers hope that the subject knows the ability in preparing a good lesson plan during a pandemic outbreak and improves the ability based on the evaluation that has been done and knows the needs and constraints of students when taking online learning using online learning platforms, especially Google Meet during the Covid-19 pandemic. The results of student constraints can be used as a reflection of teachers in preparing lesson plans by 
conducting appropriate techniques, selecting evaluation and choosing media in teaching English according to the facilities students have and support for students so that students can understand the lesson well and like learning English during the pandemic.

To improve the teacher's ability in preparing a lesson plan, faced the constraints and students' constraints it is suggested the following program activities. Firstly, EFL teacher is suggested to improve in developing teaching objectives, developing teaching materials, developing in online teaching techniques, and developing evaluation processes. Secondly, EFL teachers are suggested to faced the constraints in preparing a lesson plan, especially in selecting online teaching techniques, selecting evaluation instruments and techniques, and selecting learning media teaching EFL through Google Meet as an online learning platform by practicing more and know the students' needs or characteristics in EFL learning through Google Meet. Thirdly, EFL students and teachers are suggested to prepare well the access to high bandwidth or strong internet connection to succeed to catch up with virtual learnings or to limit the technical issues.

\section{CONCLUSION}

The result showed that in aspect 1) the highest students' constraints in understanding EFL through Google Meet $(55 \%)$ in lesson plan 4, in aspect 2) the highest students' constraints in disliking EFL through Google Meet $(51.6 \%)$ in lesson plan 4, in aspect 3 ) the highest students' constraints in being demotivated in learning EFL through Google Meet (43.3\%) in lesson plan 3, in aspect 4) the highest students' constraints in being flexible positively perceived in learning EFL through Google Meet (33.3\%) in lesson plan 3, 4 and 5, and in aspect 5) the highest students' constraints in perceiving positively to provide them with rich with learning materials, plenty of examples, or varied illustrations $(38.3 \%)$ in lesson plan 2 and 3.

\section{REFERENCES}

Abuhassna, H., Al-rahmi, W. M., Yahya, N., Aman, M., \& Megat, Z. (2020). Development of a new model on utilizing online learning platforms to improve students, academic achievements and satisfaction. International Journal of Educational Technology in Higher Education, 17(73), 2-23. https://doi.org/10.1186/s41239-020-00216-z

Agung, A. S. S. N., Surtikanti, M. W., \& Quinones, C. A. (2020). Students ' Perception o f Online Learning during COVID-19 Pandemic : A Case Study on the English Students of STKIP Pamane Talino. Jurnal Sosial Dan Humaniora, 10(2), 225-235.

Albashtawi, A. H., \& Al Bataineh, K. B. (2020). The effectiveness of google classroom among EFL students in Jordan: An innovative teaching and learning online platform. International Journal of Emerging Technologies in Learning, 15(11), 78-88. https://doi.org/10.3991/IJET.V15I11.12865

Allo, M. D. G. (2020). Is online learning good during the Covid-19 Pandemic? The case of EFL learners There is several studies on online learning so far, especially in the ESL Context. Jurnal Sinestesia, 10(1), 1-10.

Amin, F., \& Sundari, H. (2020). EFL Students ' Preferences on Digital Platforms during Emergency Remote Teaching: Video Conference, LMS, or Messenger Application? Studies in English Language and Education, 7(2), 362-378. https://doi.org/10.24815/siele.v7i2.16929

Amiti, F. (2020). Synchronous and asynchronous E-learning. European Journal of Open Education and ELearning Studies, 5(2), 60-70. https://doi.org/10.46827/ejoe.v5i2.3313

Astuti, M., \& Solikhah, I. (2021). Teacher Perception in Teaching English for SMP in Klaten Regency During Covid-19 Outbreak. IJOTL-TL, 6(1), 1-13. https://doi.org/10.30957/ijotl-tl.v6i1.645.Teacher

Atmojo, A. E. P., \& Nugroho, A. (2020). EFL classes must go online! Teaching activities and challenges during COVID-19 pandemic in Indonesia. Register Journal, 13(1), 49-76. https://doi.org/10.18326/rgt.v13i1.4976

Azzahra, N. F. (2020). Addressing Distance Learning Barriers in Indonesia Amid the Covid-19 Pandemic. Policy Brief, 2, 1-8.

Bahasoan, A., Ayuandiani, W., Mukhram, M., \& Rahmat, A. (2020). Effectiveness of Online Learning In Pandemic Covid-19. Jurnal Kajian Pendidikan Dan Hasil Penelitian, 6(3), 100-106. https://doi.org/10.46729/ijstm.v1i2.30

Binkley, M., Erstad, O., Herman, J., Raizen, S., Ripley, M., Miller-Ricci, M., \& Rumble, M. (2012). Assessment and teaching of 21st-century skills. Springer Science+Business Media, 17-66. https://doi.org/10.1007/97894-007-2324-5_2

Budiarto, M. K., Joebagio, H., \& Sudiyanto, S. (2020). Student's View of Using Digital Learning Media in Classroom Activities: A Case of Public Senior High School in Cirebon, Indonesia. Jurnal Pendidikan Progresif, 10(1). https://doi.org/10.23960/jpp.v10.i1.202006

Churchill, D., King, M., \& Fox, B. (2013). Learning design for science education in the 21 st century. Zbornik 
Instituta Za Pedagoska Istrazivanja, 45(2), 404-421. https://doi.org/10.2298/ZIPI1302404C

Creswell, J. W. (2014). Research Design : Qualitative, Quantitative and Mixed Methods Approaches (4 th). SAGE.

Farida, I., Kasim, U., \& Manan, A. (2018). Analysis Of Lesson Plans For Teaching Speaking. English Education Journal (EEJ), 9(1), 23-36.

Ferri, F., Grifoni, P., \& Guzzo, T. (2020). Online Learning and Emergency Remote Teaching: Opportunities and Challenges in Emergency Situations. Societies, 10(4), 86. https://doi.org/10.3390/soc10040086

Herviani, D., \& Budiastuti, R. E. (2018). Analisis Rencana Pelaksanaan Pembelajaran ( RPP ) Bahasa Inggris Mahasiswa Magang di SMA Negeri 9 Semarang. Prosiding Seminar Nasional Mahasiswa Unimus, 1(2015), 486-491. https://prosiding.unimus.ac.id/index.php/mahasiswa/article/view/190

Hinkle, D. E., Wiersma, W., \& Jurs, S. G. (1979). Applied Statistics For The Behavioral Sciences. Houghton Mifflin Company.

Hirschman, K., \& Wood, B. (2018). 21st-century learners: Changing conceptions of knowledge, learning, and the child. The New Zealand Annual Review of Education, 23(June), 20. https://doi.org/10.26686/nzaroe.v23i0.5280

Indah, P. (2020). Development of HOTS (High Order Thinking Skill) Oriented Learning Through Discovery Learning Model to Increase The Critical Thinking Skill of High School Students. International Journal of Chemistry Education Research,3(3). https://doi.org/10.20885/ijcer.vol4.iss1.art4

Khatoony, S., \& Nezhadmehr, M. (2020). EFL Teachers ' Challenges in the Integration of Technology for Online Classrooms during Coronavirus (Covid-19) Pandemic in Iran Shiva Khatoony. The Asian Journal of English Language \& Pedagogy, 8, 1-16.

Koswara, A. N. M. (2018). Pengaruh Kemudahaan Akses Informasi Internet Melalui Konteks Sosial Pelajar Terhadap Kecenderungan Tindakan Plagiarisme Dalam Penulisan Karya Tulis Di Kalangan Pelajar. Jurnal Masyarakat Telematika Dan Informatika, 9(1). https://mti.kominfo.go.id/index.php/mti/article/view/115

Laia, S. A. (2019). The Analysis Of English Teachers' Lesson Plans Through Objectives Theory. 2nd International Conference on Educational Assessment and Policy, 64-68.

Lassoued, Z., Alhendawi, M., \& Bashitialshaaer, R. (2020). An Exploratory Study of the Obstacles for Achieving Quality in Distance Learning during the. Educ. Sci, 10(232), 2-13.

Leatherman, J. L., \& Cleveland, L. M. (2020). Student exam performance in flipped classroom sections is similar to that in active learning sections, and satisfaction with the flipped classroom hinges on attitudes toward learning from videos. Journal of Biological Education, 54(3), 328-344. https://doi.org/10.1080/00219266.2019.1575266

Mansyur, A. R. (2020). Dampak Covid-19 Terhadap Dinamika Pembelajaran Di Indonesia. Education and Learning Journal, 1(2), 113. https://doi.org/10.33096/eljour.v1i2.55

Mayarnimar, \& Taufina. (2017). Validity Analysis of the VARK (Visual, Auditory, Read-Write, and Kinesthetic) Model-Based Basic Reading and Writing Instructional Materials for the 1st Grade Students of Elementary School. Atlantis Press, 118, 870-874. https://doi.org/10.2991/icset-17.2017.141

Mpungose, C. B. (2021). Lecturers' reflections on use of Zoom video conferencing technology for e-learning at a South African university in the context of coronavirus. African Identities. https://doi.org/10.1080/14725843.2021.1902268

Mustikawati, Y., Rasyid, M. A., Wello, M. B., \& Haryanto. (2017). A Case Study of Beginning EFL Teacher in Planning Lesson at Public Senior High School in Makassar, Indonesia. Journal of Literature, Languages and Linguistics, 31, 1-14.

Nartiningrum, N., \& Nugroho, A. (2020). Online Learning amidst Global Pandemic : EFL Students ' Challenges, Suggestions, and Needed Materials. Academic Journal of English Language and Education, 4(2), 115-140. https://doi.org/10.29240/ef.v4i2.1494

Octaberlina, L. R., \& Muslimin, A. I. (2020). EFL Students Perspective towards Online Learning Barriers and Alternatives Using Moodle / Google Classroom during COVID-19 Pandemic. International Journal of Higher Education, 9(6), 1-9. https://doi.org/10.5430/ijhe.v9n6p1

Pratama, H., Azman, M. N. A., Gulzhaina K. Kassymova, \& Duisenbayeva, S. S. (2020). The Trend in Using Online Meeting Applications for Learning During the Period of Pandemic COVID-19: A Literature Review. Journal of Innovation in Educational and Cultural Research, 1(2), 58-68. https://doi.org/10.46843/jiecr.v1i2.15

Ramkissoon, P., Belle, L. J., \& Bhurosy, T. (2020). Perceptions and experiences of students on the use of interactive online learning technologies in Mauritius. International Journal of Evaluation and Research in Education. https://doi.org/10.11591/ijere.v9i4.20692

Raynesa Noor Emiliasari. (2019). Lesson Planning in EFL Classroom: A Case Study in Lesson Plan Preparation and Implementation. Wiralodra English Journal, 3(2), 367-375. https://doi.org/10.31943/wej.v3i2.67 
Rhim, H. C., \& Han, H. (2020). Teaching online: foundational concepts of online learning and practical guidelines. Korean Journal of Medical Education, 32(3), 175-183. https://doi.org/10.3946/kjme.2020.171

Rizaldi, D. R., Nurhayati, E., \& Fatimah, Z. (2020). The Correlation of Digital Literation and STEM Integration to Improve Indonesian Students' Skills in 21 st Century. International Journal of Asian Education, 1(2), 7380. https://doi.org/10.46966/ijae.v1i2.36

Rusdin, N. M. (2018). Teachers' Readiness in Implementing 21st Century Learning. International Journal of Academic Research in Business and Social Sciences, 8(4), 1271-1284. https://doi.org/10.6007/IJARBSS/v8i4/4270

Sari, P. P. (2018). An Analysis of Lesson Plan in The 2013 Curriculum Made by English Teacher. International Conference on English Language Teaching, 1-12.

Satyawan, I. M., Wahjoedi, \& Swadesi, I. K. I. (2021). The Effectiveness of Online Learning Methods During the Covid-19 Pandemic. Journal of Education Technology, 5(2), 191-199. https://doi.org/10.2991/assehr.k.210203.093

Setyawan, A., Aznam, N., \& Citrawati, T. (2020). Effects of the Google Meet Assisted Method of Learning on Building Student Knowledge and Learning Outcomes. Universal Journal of Educational Research, 8(9), 3924-3936. https://doi.org/10.13189/ujer.2020.080917

Soucy, J. N., Owens, V. A. M., Hadjistavropoulos, H. D., Dirkse, D. A., \& Dear, B. F. (2016). Educating patients about Internet-delivered cognitive behavior therapy: Perceptions among treatment seekers and non-treatment seekers before and after viewing an educational video. Internet Interventions, 6, 57-63. https://doi.org/10.1016/j.invent.2016.09.003

Sriyanti, I., Almafie, M. R., Marlina, L., \& Jauhari, J. (2021). The effect of Using Flipbook-Based E-modules on Student Learning Outcomes. Kasuari: Physics Education Journal (KPEJ), 3(2), 69-75. https://doi.org/10.37891/kpej.v3i2.156

Storch, E. A., Sheu, J. C., \& Guzick, A. G. et al. (2021). Impact of the COVID-19 pandemic on exposure and response prevention outcomes in adults and youth with obsessive-compulsive disorder. Psychiatry Research, 295(October 2020), 113597. https://doi.org/10.1016/j.psychres.2020.113597

Sutarto, S., Sari, D. P., \& Fathurrochman, I. (2020). Teacher Strategies in Online Learning to Increase Students ' Interest in Learning During COVID-19 Pandemic. Jurnal Konseling Dan Pendidikan, 8(3), 129-137. https://doi.org/10.29210/147800

Tondeur, J., Scherer, R., Baran, E., Siddiq, F., Valtonen, T., \& Sointu, E. (2019). Teacher educators as gatekeepers: Preparing the next generation of teachers for technology integration in education. British Journal of Educational Technology, 50(3), 1189-1209. https://doi.org/10.1111/bjet.12748

Windhiyana, E. (2020). Dampak Covid-19 Terhadap Kegiatan Pembelajaran Online Di Perguruan Tinggi Kristen Di Indonesia. Perspektif Ilmu Pendidikan, 34(1), 1-8. https://doi.org/10.21009/pip.341.1

Wu, S.-C. (Angel), \& Chang, Y.-L. (Aldy). (2015). Advancing Kindergarten Teachers' Knowledge and Capabilities of Differentiated Instruction Associated with Implementation of Thematic Integrated Curriculum. Procedia - Social and Behavioral Sciences, 177. https://doi.org/10.1016/j.sbspro.2015.02.404

Yafaei, Y. Al, \& Attamimi, R. (2019). Understanding Teachers' Integration of Moodle in EFL Classrooms: A Case Study. English Language Teaching, 12(4). https://doi.org/10.5539/elt.v12n4p1

Yunitasari, R., \& Hanifah, U. (2020). Pengaruh Pembelajaran Daring terhadap Minat Belajar Siswa pada Masa COVID 19. Edukatif: Jurnal Ilmu Pendidikan, 2(3), 232-243. https://doi.org/10.31004/edukatif.v2i3.142

Yusoff, W. M. W., \& Seman, S. C. (2018). Teachers' Knowledge of Higher Order Thinking and Questioning Skills: A Case Study at a Primary School in Terengganu, Malaysia. International Journal of Academic Research in Progressive Education and Development, 7(2), 45-63. https://doi.org/10.6007/ijarped/v7i2/4120

Zain, I. M. (2017). The Collaborative Instructional Design System (CIDS): Visualizing the 21st Century Learning. Universal Journal of Educational Research, 5(12), 2259-2266. https://doi.org/10.13189/ujer.2017.051216 